University of Nebraska - Lincoln

DigitalCommons@University of Nebraska - Lincoln

To Improve the Academy

Professional and Organizational Development Network in Higher Education

1997

Section III: Assessing Faculty Development Activities

Follow this and additional works at: https://digitalcommons.unl.edu/podimproveacad

Part of the Higher Education Administration Commons

"Section III: Assessing Faculty Development Activities" (1997). To Improve the Academy. 390.

https://digitalcommons.unl.edu/podimproveacad/390

This Article is brought to you for free and open access by the Professional and Organizational Development Network in Higher Education at DigitalCommons@University of Nebraska - Lincoln. It has been accepted for inclusion in To Improve the Academy by an authorized administrator of DigitalCommons@University of Nebraska - Lincoln. 


\section{Section III:}

\section{Assessing Faculty Development Activities}

